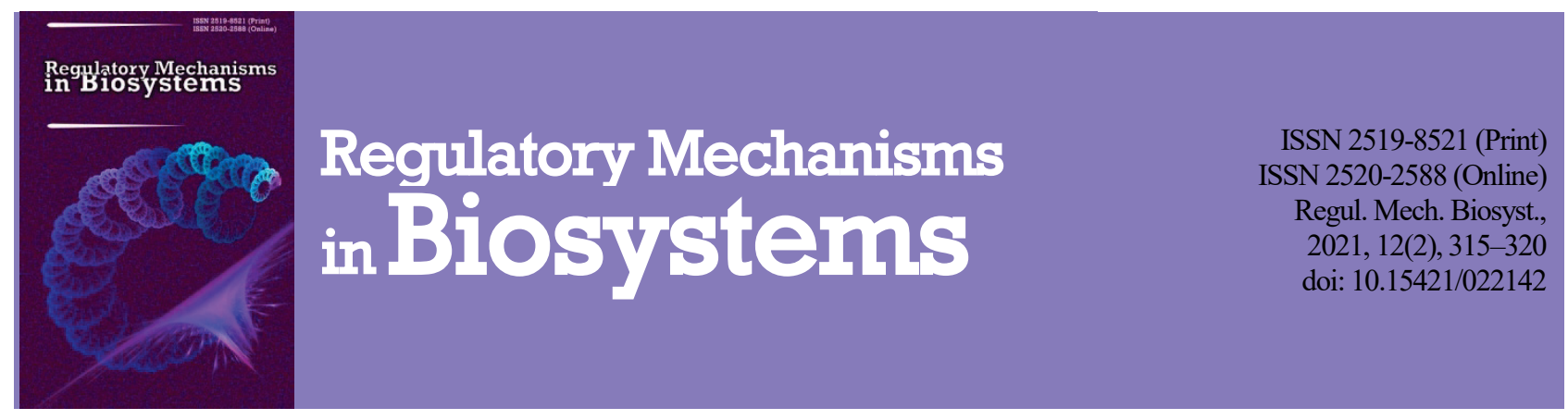

\title{
Antioxidant status of the organisms of young bulls in the conditions of lead-cadmium load and effect of correcting factors
}

\author{
S. O. Slobodian*, B. V. Gutyj*, L. M. Darmohray*, M. G. Povoznikov** \\ *Stepan Gzhytskyi National University of Veterinary Medicine and Biotechnologies Lviv, Ukraine \\ **National University of Life and Environmental Sciences of Ukraine, Kyiv, Ukraine
}

Article info

Received 15.04.2021

Received in revised form 25.05.2021

Accepted 27.05.2021

Stepan Gzhytskyi

National University

of Veterinary

and Biotechnologies Lviv

Pekarska st., 50,

Lviv, 79010, Ukraine.

$\mathrm{Tel} \cdot \mathbf{+}+38-068-136-20-54$

E-mail:bvh@ukr.net

National University

of Life and Environmental

Sciences of Ukraine,

Heroyiv Oborony st., 15 ,

Kyiv, 03041, Ukraine.

Tel.: +38-067-384-08-75.

E-mail:povoznikov@i.ua

Slobodian, S. O., Gutyj, B. V., Darmohray, L. M., \& Povoznikov, M. G. (2021). Antioxidant status of the organisms of young bulls in the conditions of lead-cadmium load and effect of correcting factors. Regulatory Mechanisms in Biosystems, 12(2), 315-320. doi:10.15421/022142

Prolonged ingress of heavy metals into the organisms of animals, even in low concentrations, causes a number of toxic impacts, affecting various organs and systems. The objective of this study was to research parameters of enzymatic and non-enzymatic links of the system of antioxidant protection of the organism of young cattle in the condition of lead-cadmium load and the effect of Metisevit Plus feed additive. Studies were conducted on the basis of the Private Agricultural Company "Ukraina", located in Dubrovytsia district of Rivne Oblast, using 12 six-month old bulls of Ukrainian Black Pied Dairy breed divided into two groups, each consisting of 6 animals. Bulls of the control group received the standard diet. The bulls of the experimental group were fed with Metisevit Plus feed additive in the dose of $0.5 \mathrm{~g} / \mathrm{kg}$ of feed. The contents of lead and cadmium in feed at the enterprise were determined to be high. According to the conducted studies, it was determined that in conditions of cadmium and lead load, there is a decrease in activity of glutathione link of the system of antioxidant protection of the organism of bulls. Feeding the bulls of the experimental group with Metisevit Plus feed additive for 30 days led to increase in the levels of non-enzymatic and enzymatic activities of the glutathione system. Significant increase in the level of reduced glutathione was recorded on days 30 and 40 of the experiment. Consumption of Metisevit Plus by the animals of the experimental group promoted increase in the activity of catalase and superoxide dismutase starting on the 20th day of the experiment. On days 30 and 40 of the experiment, the activity of the studied enzymes ranged within the physiological values. Therefore, the studies conducted on the bulls indicate that in the conditions of cadmium and lead load the feed additive Metisevit Plus fed to the bulls activated the system of antioxidant protection by increasing the levels of enzymatic and nonenzymatic links. When feeding bulls of the experimental group with Metisevit Plus feed additive, we determined significant decreases in diene conjugates and TBA-active products in their blood starting already on the 10th day of the experiment. On days 20 and 30 of the experiment, the level of diene conjugates in the blood of animals of the experimental group decreased by $14.5 \%$ and $24.0 \%$. Efficiency of the feed additive may be explained by the effect of its constituents on the main pathogenic links of the pathological process caused by cadmium and lead. As indicated in the studies, liquidation of the syndrome of endogenous intoxication restores the functional condition of cellular membranes of the liver, protein-synthesizing function of the liver, increases the antioxidant status of the organisms of bulls. The studies we conducted confirm the expedience of using feed additive Metisevit Plus to prevent lead-cadmium toxicosis.

Keywords: technogenic load; antioxidant activity; lipid peroxidation; feed additive.

\section{Introduction}

In the conditions of contemporary technogenic pollution of the environment, ecological problems, improving the quality of livestock products and food safety are important and relevant issues today (Ercal et al., 2001; Vishchur et al., 2019; Yaroshevych et al., 2021).

Due to deterioration of the ecological situation, it is a matter of high priority to monitor heavy metals in the trophic chain; soil - plant - food animal - products - human. These pollutants quickly migrate and concentrate in biosphere components (air, water, soil - plants - animals - human), thereby complicating the production of high-quality agricultural production and negatively affecting human health (Fryzova et al., 2018; Rehman et al., 2018; Zazharska et al., 2018; Fu \& Xi, 2020). Therefore, it is necessary to select such a system of livestock rearing that will correspond to the expected productivity in order to obtain maximum amount of safe high-quality products that meet sanitary standards (Fan et al., 2015).

Heavy metals are the leading pollutants of the atmosphere, water bodies and soils on a global and regional scale. Due to their high migratory ability, tendency toward bioaccumulation and poly-trophic nature, metals pose a dangerous threat to humans and animals not only by direct impact, but also through negative impact on sanitary-hygienic parameters of environmental objects (Shulman et al., 2017; Kozak \& Brygadyrenko, 2018; Pratush et al., 2018; Sall et al., 2020; Piven et al., 2020). Mixture of toxic substances that are able affect living organisms both independently and interacting with one another in various ways may influence the extent of toxic effects of separate substances (Ali et al., 1986; Kalyn et al., 2020). Therefore, during environmental contamination with heavy metals, it was confirmed that manifestations of toxic action may depend on presence of interaction between them, which causes changes in the threshold values, and thus, not only is the toxicity of each component of the system important, but their combined action as well (Järup, 2003; Rahman \& Singh, 2019, 2020).

Among the environmental pollutants, cadmium and lead occupy two of the top positions in terms of toxicity and danger to humans and animals (Al-Azemi et al., 2010; Renu et al., 2021). Prolonged contact with these metals and their ingress into the organism of animals, even in small concentrations, inhibit the immune system of the organisms of animals, reduce their resistance to infections and promote development of allergic, 
autoimmune and oncologic pathologies. These metals block reactive (sulfhydryl, carboxyl and phosphate) groups of biopolymers, including proteins, nucleic acids, enzymes (Fregoneze etal., 1997; Gutyj et al., 2019). When entering the organisms of animals, heavy metals not only reduce their productivity (Gutyj et al., 2016), but affect the chemical composition, indicators of biological value and sanitary quality of livestock products (Slobodian et al., 2019). Feeds contaminated by even a small amount of heavy metals may be a cause of chronic and subclinical intoxication of animals.

In general, the mechanism of combined action of cadmium and lead on the organism of young cattle still has not been revealed completely, though the main, most universal positions based on knowledge of the metabolic pathways of heavy metals are studied quite well. Therefore, it is necessary to study the pharmacologic-toxicological and biochemical processes that lie at the base of metabolic disorders and impairments of vital functions of the organisms of animals, caused by combinative action of lead and cadmium. It is especially important to determine the effect of these toxicants on the system of antioxidant protection of the organisms of animals, which prevents the excessive activations of free-radical and peroxide reactions in the organisms of animals and to perform a search for drugs that would be able to increase the resistance of the organism to diseases by inhibiting combined toxic effects of salts of heavy metals.

Especially interesting is the condition of the system of antioxidant protection of the organism of animals in the conditions of various physiological disorders and pathological conditions of the organism, including those caused by toxic effect of heavy metals (Grymak et al., 2020). According to the literature data, heavy metals disturb this balance between the formation of prooxidants in the organism and their deactivation by antioxidants, which, as a result, causes development of oxidative stress (El-Shahat et al., 2009; Gutyj et al., 2017).

Research on the glutathione system in the conditions of negative effects of heavy metals is relevant not only in the context of functioning of the general antioxidant system of the organism, but also due to its direct involvement in many biochemical mechanisms of detoxification of lipophilic and hydrophilic xenobiotics. Participation of glutathione and systems connected with it in the processes of biotransformation and detoxication of xenobiotics is to a high degree determined by resistance of the organism against their toxic action.

The objective of the study was to research the antioxidant status of the organisms of bulls in the conditions of lead-cadmium load and action of the feed additive Metisevit Plus.

\section{Materials and methods}

All the manipulations with the animals were conducted according to the European Convention for the Protection of Vertebrate Animals used for Experimental and other Scientific Purposes (Official Journal of the European Union L276/33, 2010). The research was performed on the basis of the Private Agricultural Enterprise "Ukraina" of Dubrovytsia district of Rivne Oblast on 12 six month old bulls of the Ukrainian Black Pied Dairy Breed separated into 2 groups with 6 animals in each.

Group 1 was the control group (C), where the bulls were given the standard diet; group 2 was the experimental group (E) in which the bulls received Metisevit Plus in the dose of $0.5 \mathrm{~g} / \mathrm{kg}$ of compound feed.

In this enterprise, the feeds were determined to contain high contents of lead and cadmium. At the same time, we determined significant differences between the accumulations of these metals between the different types of feeds. The greatest content of cadmium was found in grain feeds and concentrated feeds, where its concentrations exceeded threshold limit value by 1.39 (wheat); 1.35 (rye); 1.23 (barley) times. As for lead, its highest content was in juicy feeds, particularly in leaf vegetable of feed beet, exceeding the allowable level by $79.1 \%$; in green mass of herbs in natural pastures - correspondingly by $69.3 \%$ and $76.4 \%$; herbage of mixture with Vica sativa - by $69.2 \%$ and $70.7 \%$.

To conduct the studies, we followed the compulsory rules for performance of zootechnical experiments on selection and maintenance of analogue animals in the groups, technologies of preparation, use and accounting of consumed feeds. To prevent negative impact of cadmium and lead on the organisms of animals, at the Department of Pharmacology and
Toxicology of the Lviv National University of Veterinary Medicine and Biotechnologies named after S. Z. Gzhutsky, the feed additive Metisevit Plus was developed based on phenaron, vitamins $\mathrm{A}$ and $\mathrm{E}$, methionine, selenium and zinc.

Blood for the analyses was drawn from the jugular vein at the beginning of the experiment and on days 10,20,30 and 40 after feeding the bulls with Metisevit Plus additive.

Activities of glutathione peroxidase (GP; E.C.1.11.1.9) and glutathione reductase (GR; E.C.1.6.4.2) were determined using the method of Lemeshko et al. (1985); activity of catalase (CT; E.C.1.11.1.6) - using the method of Koroliuk (1988); activity of superoxide dismutase (SOD; E.C.1.15.1.1) - using the method of Dubinina et al. (1983); the level of TBA-active products - using the method of Korobeinikov (1989), level of diene conjugants - method of Stalna (1977); content of reduced glutathione (RG) was determined using the method of Butler (1963) (Vlislo, 2012).

The data were analyzed using Statistica 6.0 software pack (StatSoft Inc., USA). The data are presented in the diagrams as $\mathrm{x} \pm \mathrm{SD}(\mathrm{x} \pm$ standard deviation). Differences between the values of the control and the experimental groups were determined using ANOVA, where the differences were considered statistically reliable at $\mathrm{P}<0.05$ (taking into account Bonferroni correction).

\section{Results}

The studies revealed that cadmium and lead load led to decrease in the activity of the glutathione link of the system of antioxidative protection. Therefore, we observed decrease in the level of reduced glutathione to $29.58 \pm 0.55 \mathrm{mg} \%$ in blood of bulls of the control group loaded by heavy metals.

Feeding bulls of the experimental group with Metisevit Plus feed additive for 30 days caused increase in the level of reduced glutathione throughout the experiment. Therefore, on day 10 of the experiment, the level of the parameter in the blood of animals of the experimental group increased to $30.62 \pm 0.54 \mathrm{mg} \%$, while equaling $29.59 \pm 0.49 \mathrm{mg} \%$ in the control group. Significant increase in the level of reduced glutathione was seen on days 30 and 40 of the experiment, where it increased by $7.6 \%$ and $7.1 \%$ respectively compared with the control group (Fig. 1).
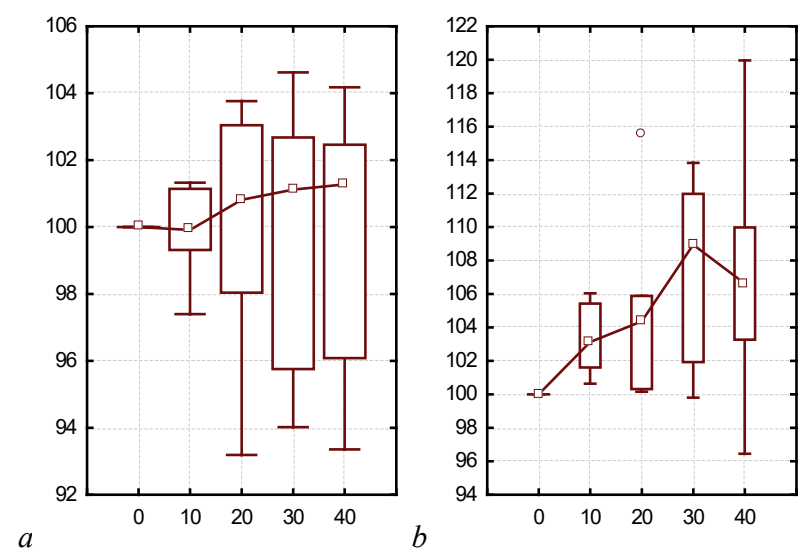

Fig. 1. Level of reduced glutathione in the blood of bulls of the control group $(a)$ and bulls of the experimental group in the conditions of leadcadmium load and effect of feed additive Metisevit Plus $(b)$ : along abscissa axis - day of the experiment, along the ordinate axis - the level of reduced glutathione (\% against the initial level of reduced glutathione before the beginning of the experiment, considered $100 \%$ for each of the experimental animals); small square - median, upper and lower edges of the rectangular square $-75 \%$ and $25 \%$ of quartile, vertical line - minimum and maximum values, circles - outliers; $n=6$

The research performed on activity of separate enzymes of the glutathione link of the system of antioxidative protection in blood of bulls of the control and experimental groups revealed that the activities of glutathione peroxidase and glutathione reductase at the beginning of the experiment ranged within $29.4-28.9 \mathrm{nmol}$ of $\mathrm{NADPH} / \mathrm{min}$ per $1 \mathrm{mg}$ of protein and 
$1.33 \pm 0.040$ and $1.35 \pm 0.033 \mathrm{nmol}$ of NADPH$/ \mathrm{min}$ per $1 \mathrm{mg}$ of protein (Fig. 2 and 3).

When feeding Metisevit Plus additive to bulls of the experimental group, we determined a significant increase in the activity of glutathione peroxidase starting already on day 30 of the experiment, when the activity of the enzyme increased by $23.5 \%$ compared with the control group of animals. On day 40 of the experiment, the activity of glutathione peroxidase in the blood serum of bulls of the experimental group was $21.3 \%$ higher compared with the control group.
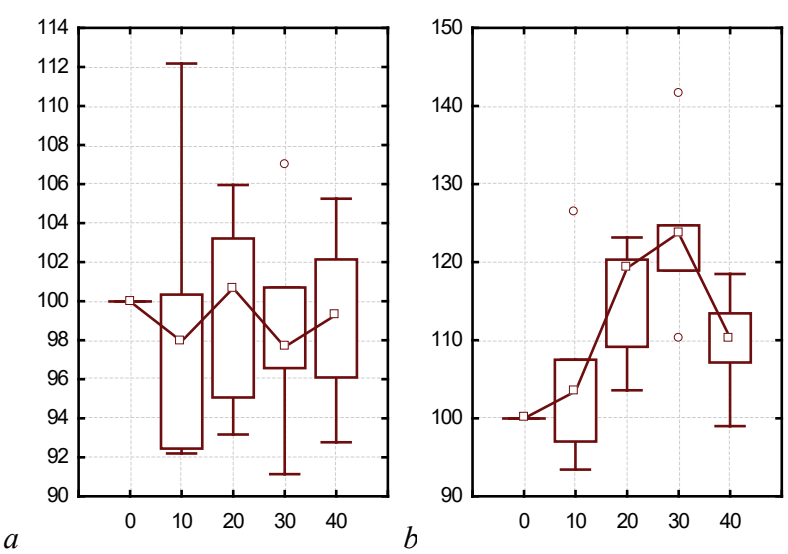

Fig. 2. Activity of glutathione peroxidase in blood serum of bulls of the control group $(a)$ and bulls of the experimental group in the conditions of lead-cadmium load and action of feed additive Metisevit Plus (b): on abscissa axis - day of the experiment, on ordinate axis - activity of glutathione peroxidase (\% of the initial activity of glutathione peroxidase before the beginning of the experiment, considered $100 \%$ for every experimental animal); small square - median, upper and lower edges of the rectangular square $-75 \%$ and $25 \%$ of quartile, vertical line - minimum and maximum values, circles - outliers; $n=6$

Studies of the activity of glutathione reductase in the blood serum of bulls of the experimental group revealed that consumption of Metisevit Plus feed additive led to a significant increase of the activity of this enzyme starting already on the 10th day of the experiment, when it equaled $1.42 \pm 0.050 \mathrm{nmol}$ of $\mathrm{NADPH} / \mathrm{min}$ per $1 \mathrm{mg}$ of protein, whereas in the control group it was $1.31 \pm 0.034 \mathrm{nmol}$ of NADPH/min per $1 \mathrm{mg}$ of protein. On days 20 and 30 of the experiment, the activity of glutathione reductase in the blood serum of bulls of the experimental group increased by $10.2 \%$ and $24.6 \%$ compared with the control. On day 40 of the experiment, the activity of the enzyme in blood of the experimental group remained high, equaling respectively $1.64 \pm 0.039 \mathrm{nmol}$ of NADPH/min per $1 \mathrm{mg}$ of protein.

We determined inhibition of activity of catalase in the blood of bulls of the control and experimental groups at the beginning of the experiment. Activity of this enzyme remained low in the blood of the control group, whereas in the experimental group, the activity of catalase significantly increased beginning already from the 20th day of the experiment, by $14.4 \%$ respectively compared with the control group. On days 30 and 40 of the experiment, activity of catalase in the blood of bulls of the experimental group remained high, equaling $6.62 \pm 0.19$ units on the 30th day, and $6.55 \pm 0.17$ units on the 40th day (Fig. 4).

The studies of the activity of superoxide dismutase revealed that it was low in the blood of animals of the control group, ranging respectively $0.45-0.50$ conventional units $/ \mathrm{mg}$ of protein. In the experimental group of bulls activity of this enzyme was observed to be significantly increased as soon as the 10th day of feeding with Metisevit Plus. On day 20 of the experiment, the activity of superoxide dismutase in the blood of bulls of the experimental group significantly increased by $16.3 \%$ compared with the bulls of the control group (Fig. 5).

On the 30th day of the experiment, the activity of superoxide dismutase in the blood of bulls of the experimental group was the highest, equaling $0.63 \pm 0.013$ conventional units $/ \mathrm{mg}$ of protein against the control, where it was $0.46 \pm 0.010$ conventional units/mg of protein, thus being $37.0 \%$ higher than the parameters of the control group.
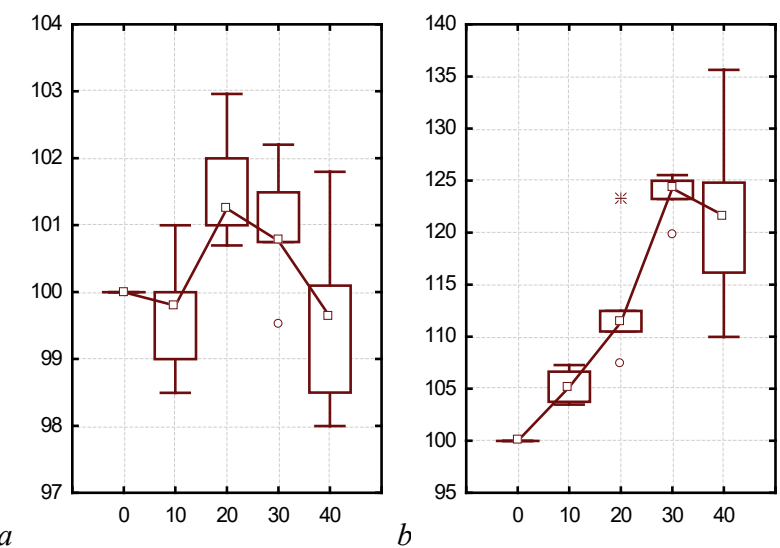

Fig. 3. Activity of glutathione reductase in blood serum of bulls of the control group $(a)$ and bulls of the experimental group in the conditions of

lead-cadmium load and action of Metisevit Plus feed additive $(b)$ : on abscissa axis - day of the experiment, on ordinate axis - activity of glutathione reductase $(\%$ of the initial activity of glutathione reductase before the beginning of the experiment, considered $100 \%$ for every experimental animal); small square - median, upper and lower edges of the rectangular square $-75 \%$ and $25 \%$ of quartile, vertical - minimum and maximum values, circles - outliers; $n=6$
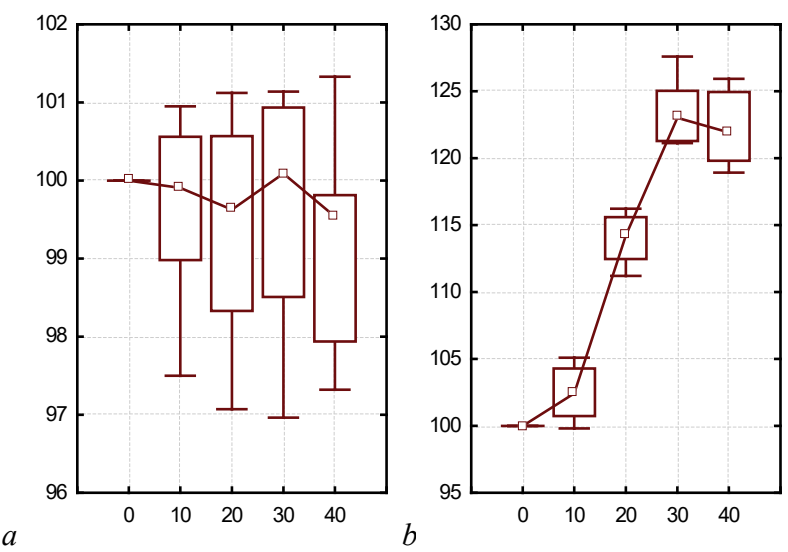

Fig. 4. Activity of catalase in the blood serum of bulls of the control group (a) and bulls of the experimental group in the conditions of lead-cadmium load and effect of feed additive Metisevit Plus (b): on abscissa axis - day of the experiment, on ordinate axis - activity of catalase ( $\%$ of the initial activity of catalase before the experiment, considered $100 \%$ for each of the experimental animals); small square - median, upper and lower edges of the rectangular square $-75 \%$ and $25 \%$ of quartile, vertical line - minimum and maximum values; $n=6$

We determined that the process of peroxidation of lipids in the blood of bulls intensified in the conditions of heavy metal load. The levels of the primary and end products of lipid peroxidation in the blood of bulls of the control and experimental groups at the beginning of the experiment equaled $7.60 \pm 0.18$ and $7.62 \pm 0.10 \mu \mathrm{mol} / \mathrm{L}$ and $0.298 \pm 0.007$ and $0.302 \pm$ $0.005 \mu \mathrm{mol} / \mathrm{L}$. In the subsequent periods of the study, the levels of primary and end products of lipid peroxidation in the blood of bulls of the control group were increasing and remained high throughout the experiment.

When feeding bulls of the experimental group with Metisevit Plus feed additive, we determined significant decrease in diene conjugates in their blood starting already on the 10th day of the experiment, equaling $6.4 \%$ compared with the parameters of the control group (Fig. 6).

On days 20 and 30 of the experiment, the level of diene conjugates in the blood of animals of the experimental group continued to decrease, falling by $14.5 \%$ and $24.0 \%$ compared with the control group respectively. On day 40 of the experiment, the level of primary products of lipid peroxidation in the animals ranged within the values of the previous day of the experiment.

Feeding bulls with Metisevit Plus feed additive also led to decrease in the end products of lipid peroxidation in the blood of animals of the expe- 
rimental group. We determined that the level of TBA-active products in the blood of bulls of the experimental group decreased by $6.6 \%$ on the 10th day of the experiment, and by $13.0 \%$ on the 20 th day compared with the control group of animals.
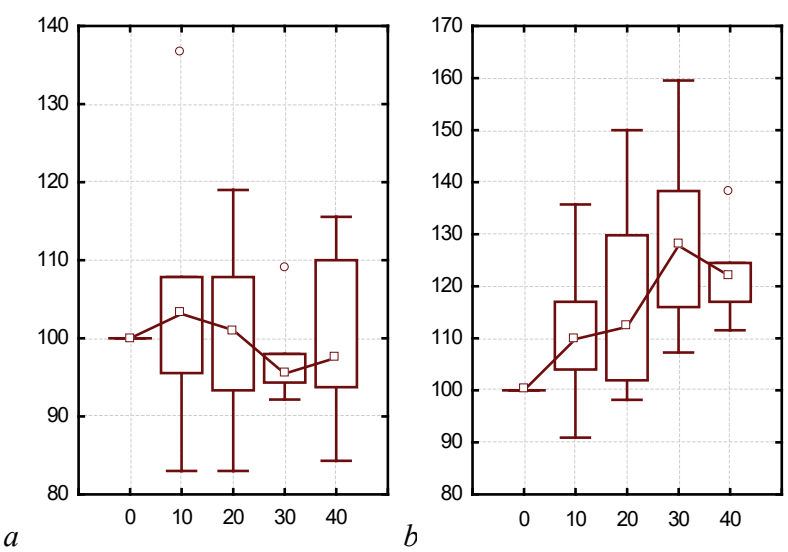

Fig. 5. Activity of superoxide dismutase in the blood serum of bulls of the control group $(a)$ and bulls of the experimental group in the conditions of lead-cadmium load and action of Metisevit Plus feed additive $(b)$ : on abscissa axis - day of the experiment, on ordinate axis - activity of superoxide dismutase $(\%$ of the initial activity of superoxide dismutase before the experiment, considered $100 \%$ for every experimental animal); small square - median, the upper and lower edges of the rectangular square $-75 \%$ and $25 \%$ of quartile, vertical line - minimum and maximum values, circles - outliers; $\mathrm{n}=6$

On day 30 of the experiment, we determined the lowest level of end products of lipid peroxidation in the blood of animals of the experimental group, where it ranged within $0.246 \pm 0.010 \mu \mathrm{mol} / \mathrm{L}$, compared with $0.304 \pm 0.006 \mu \mathrm{mol} / \mathrm{L}$ in the control group.

On day 40 of the experiment, the level of TBA-active products in blood of bulls fed with Metisevit Plus feed additive remained low compared with the control group, where it decreased by $19.7 \%$ respectively (Fig. 7). Thus, consumption of feed additive by the bulls in the conditions of cadmium and lead load led to reduction in the processes of lipid peroxidation in their organism, particularly the level of the primary and end products: diene conjugates and TBA-active products.

\section{Discussion}

Our earlier studies determined that there was a background level of separate microelements, lead and cadmium in different fodders grown for feeding animals at the Shevchenko Agricultural Enterprise in Zdolbuniv district, Agricultural Production Cooperative Nyva located in Dubno District and Agricultural Enterprise "Ukraina" in Dubrovytsia district of Rivne Oblast. High content of lead and cadmium was determined in fodders of Nyva Cooperative of Dubno district and "Ukraina" Enterprise of Dubrovytsia district. At the same time, a great difference was determined in accumulations of these metals between different types of fodder (Slivinska et al., 2019; Slobodian et al., 2020).

The highest content of cadmium was determined in grain and concentrated feeds, where its concentration exceeded the threshold limit value by 1.39 (wheat), 1.35 (rye) and 1.23 (barley) times at the Agricultural Enterprise "Ukraina" and respectively 1.37, 1.20 and 1.03 times at the Nyva Cooperative. Cadmium level exceeding the TLV was determined in feed beet and sugar beet, exceeding it respectively by $39 \%$ and $32 \%$.

As with lead, its highest content was in juicy feeds, particularly leaf vegetables of feed beet at the "Ukraina" enterprise, being $79.1 \%$ higher than the TLV and $45.7 \%$ at the Nyva Cooperative; in green mass of herbs in natural pastures - respectively by $69.3 \%$ and $76.4 \%$; herbage of mixture with Vicia sattiva - by $69.2 \%$ and $70.7 \%$ higher than threshold limit value.

As a result of the conducted studies of feeds, we determined high contents of heavy metals: cadmium and lead, which respectively pose a certain threat to the health of animals, quality of the production, and ultimate- ly - human health. Thus, it would be practical to introduce antagonists of those heavy metals to the diets in specialized mineral additives.

Currently, there is a large amount of reports about important role of the system of antioxidative protection in animals during development of toxicoses caused by heavy metals (Gutyj et al., 2016; Ivankiv et al., 2019; Vasylyev et al., 2021). Therefore, it was important to study the impact of the feed additive Metisevit Plus on enzymic activity of the antioxidant system and glutathione link of the organisms of bulls in the conditions of technogenic pressure from lead and cadmium.
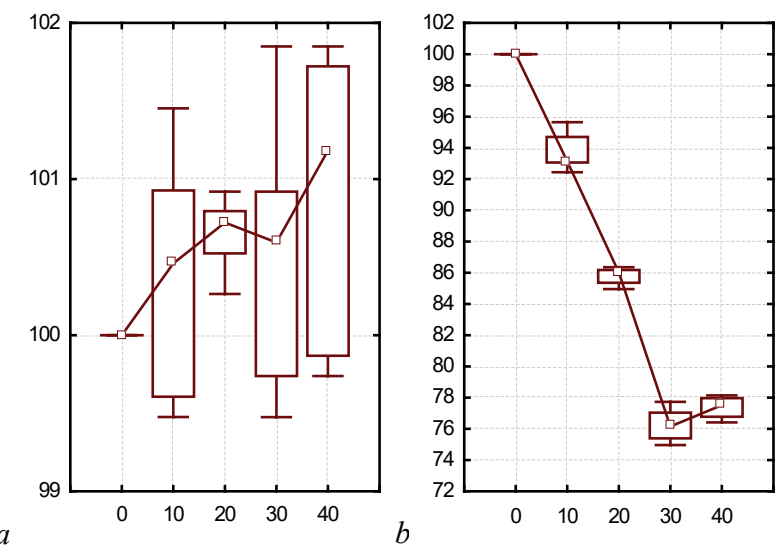

Fig. 6. Level of diene conjugates in the blood of bulls of the control group (a) and bulls of the experimental group in the conditions of lead-cadmium load and action of Metisevit Plus feed additive (b): on abscissa axis - day of the experiment, on ordinate axis - level of diene conjugates ( $\%$ of the initial level of diene conjugates before the experiment, considered $100 \%$ for every experimental animal); small square-median, upper and lower edges of rectangular square $-75 \%$ and $25 \%$ of quartile, vertical lineminimum and maximum values; $\mathrm{n}=6$
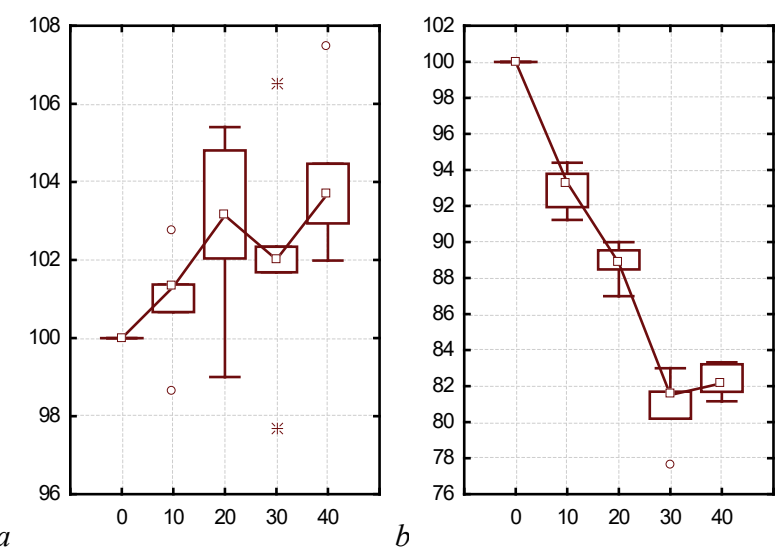

Fig. 7. Level of TBA-active products in the blood of bulls of the control group $(a)$ and bulls of the experimental group in the conditions of leadcadmium load and action of Metisevit Plus feed additive $(b)$ : on abscissa axis - day of the experiment, on ordinate axis - level of TBA-active products ( $\%$ of the initial level of TBA-active products before the experiment, considered $100 \%$ for every experimental animal); small square - median, the upper and lower edges of the rectangular square - $75 \%$ and $25 \%$ of quartile, vertical line - minimum and maximum values, circles - outliers; $n=6$

According to the conducted studies, in the conditions of cadmium and lead load, the activity of the glutathione link of the system of antioxidative protection of the organism of bulls decreased (Gutyj et al., 2017). Feeding bulls of the experimental group with Metisevit Plus for 30 days increased the level of non-enzymatic and enzymatic activities of the glutathione system. Significant increase in the level of reduced glutathione was seen on days 30 and 40 of the experiment. During the study of the activity of glutathione peroxidase and glutathione reductase, we determined that in the indicated periods of the study they ranged within $35.7 \pm 1.61$ and $35.3 \pm$ $1.55 \mathrm{nmol}$ of $\mathrm{NADPH} / \mathrm{min}$ per $1 \mathrm{mg}$ of protein $(\mathrm{P}<0.01)$ and $1.67 \pm 0.041$ 
and $1.64 \pm 0.039 \mathrm{nmol}$ of NADPH/min per $1 \mathrm{mg}$ of protein $(\mathrm{P}<0.001)$. Consumption of Metisevit Plus feed additive by bulls of the experimental group significantly increased catalase activity starting already from the 20th day of the experiment. On days 30 and 40 of the experiment, the activity of the studied enzyme ranged within physiological values.

At the same time, superoxide dismutase activity was in a certain relationship with the intensity of peroxidation processes in the tissues of animals. Feeding bulls of the experimental group with Metisevit Plus increased the activity of superoxide dismutase in their blood serum, and on the 30th day of the experiment the activity of the studied enzyme varied within $0.63 \pm 0.013$ conventional units $/ \mathrm{mg}$ of protein against the control, equaling $0.46 \pm 0.010$ conventional units $/ \mathrm{mg}$, which was $37.0 \%$ higher than the parameters of the control group.

Therefore, the studies performed on bulls indicate that Metisevit Plus feed additive, when fed to bulls in the conditions of cadmium and lead load, promoted activation of the system of antioxidative protection through increase in the level of its enzymatic and non-enzymatic links.

The analysis of the obtained results also indicates that superoxide dismutase activity in blood serum of bulls of the experimental group positively correlated with the activity of catalase.

Lipid peroxidation is one of the most important oxidative processes in the organism of animals (Slobodian et al., 2019). It is oxidative degradation of lipids, occurring under the action of free radicals and is one of the main causes of damage to cellular membranes and further death of cells as a result of influence of reactive oxygen species. The main initiators of free radical oxidation are reactive oxygen species (ROS) that are able to grow under the influence of unsatisfactory factors, including heavy metals and cause oxidative stress (Stoyanovskyy et al., 2020).

Normalization of the processes of lipid peroxidation is an important aspect of solving problems of correction of pathological changes in the context of technogenic load. Based on our studies, we determined increase in processes of lipid peroxidation in blood of bulls in the conditions of heavy metal load, which is indicated by increased level of diene conjugates and TBA-active products. Products of lipid peroxidation negatively affect the membranes of liver cells. An important role in realization of the toxic impact of cadmium and lead is played by activation of lipid peroxidation, expressed depending on antioxidant protection and intensity of generation of reactive oxygen species.

As for effects of correction on disorders in the process of lipid peroxidation and antioxidant system, of great interest is the use of the Metisevit Plus feed additive. The bulls of the experimental group that had consumed Metisevit Plus feed additive were observed to have significant decreases in diene conjugates and TBA-active products and their blood starting already on the 10th day of the experiment. On days 20 and 30 of the experiment, the level of diene conjugates in the blood of animals of the experimental group decreased by $14.5 \%$ and $24.0 \%$. On the 30th day of the experiment, we observed the lowest level of end products of lipid peroxidation in the blood of animals of the experimental group.

The effectiveness of the feed additive may be explained by the impact of its constituents based on the pathogenic link of the pathological process caused by cadmium and lead (Slobodian et al., 2020). Inclusion of selenium in the composition of feed additive prevented the absorption of cadmium and lead in the digestive tract. It has to be noted that in the organism of animals, selenium stimulates metabolic processes, its main biochemical function is participation in the development and functioning of enzyme of glutathione system - glutathione peroxidase, and also glycerine reductase and cytochrome 3 (Martyshuk et al., 2020). Selenium is an antagonist of mercury and arsenic, and is able to protect the organism against cadmium, lead, thallium (Sobolev et al., 2018).

Zinc promotes absorption of vitamin $\mathrm{E}$ and supports the normal concentration of this vitamin in the blood. It intensifies the immune system of the organism and has a detoxifying action by removing carbon dioxide from the organism. Zinc takes part in the development of T-cellular immunity, functioning of dozens of enzymes, and also antioxidant enzyme of superoxide dismutase (Muhamed \& Vadstrup, 2014; Kogan et al., 2017).

According to the literature data, the highest antioxidant property among the compounds of the phenol series in the organism of animals was exerted by tocopherols. Their antioxidative role is due to localization in phospholipid layers of cellular membranes and direct contact with unsaturated fatty acids which tocopherols protect against the destructive impact of free radicals (Di Vincenzo et al., 2019; Yang et al., 2020).

Methionine is a vitally important amino acid that takes part in protein synthesis, and also is a universal source of methyl groups, synthesis of which in the organism is limited. Methionine is an important source of sulfur in the organism. It is involved in synthesis of sulfuric acid that is essential for disabling some metabolic products in the liver of animals (Albrecht et al., 2017; Tombarkiewicz et al., 2020).

The antioxidant fenaron, which is present in the content of the feed additive, prevents oxidation of fats and decreases the content of free radicals and products of lipid peroxidation. Moreover, an activating effect of fenaron on enzymes of glutathione link of antioxidant system was determined: glutathione peroxidase, glutathione reductase and glucose-6-phosphate dehydrogenase (Nazaruk et al., 2015).

As shown in the research, liquidation of syndrome of endogenous intoxication promotes restoration of functional condition of the liver cell membranes, protein-synthesizing function of the liver, increase in antioxidant status of the organism of young bulls.

The studies we conducted confirm the expedience of using the feed additive Metisevit Plus for prevention of lead-cadmium toxicosis.

\section{Conclusions}

Metisevit Plus feed additive fed to bulls in the conditions of cadmium and lead load promotes activation of the system of antioxidant protection as a result of increasing the level of its enzymatic and non-enzymatic links, particularly: reduced glutathione - by $7.6 \%(\mathrm{P}<0.05)$, glutathione peroxidase - by $23.5 \%(\mathrm{P}<0.01)$, glutathione reductase - by $24.6 \%(\mathrm{P}<0.001)$, catalase - by $23.0 \%(\mathrm{P}<0.001)$ and superoxide dismutase - by $36.9 \%$ $(\mathrm{P}<0.001)$. Also, this feed additive reduced the processes of lipid peroxidation in their organism, particularly the level of its primary and end products: diene conjugates - by $24.0 \%(\mathrm{P}<0.001)$, and TBA-active products by $19.7 \%(\mathrm{P}<0.001)$.

This scientific work was financially supported by the Ministry of Education and Science of Ukraine (0120U101999).

\section{References}

Al-Azemi, M., Omu, F. E., Kehinde, E. O., Anim, J. T., Oriowo, M. A., \& Omu, A. E. (2010). Lithium protects against toxic effects of cadmium in the rat testes. Joumal of Assisted Reproduction and Genetics, 27(8), 469-476.

Albrecht, A., Herbert, U., Miskel, D., Heinemann, C., Braun, C., Dohlen, S., Zeitz J. O., Eder, K., Saremi, B., \& Kreyenschmidt, J. (2017). Effect of methionine supplementation in chicken feed on the quality and shelf life of fresh poultry meat. Poultry Science, 96(8), 2853-2861.

Ali, M. M., Murthy, R. C., \& Chandra, S. V. (1986). Developmental and longterm neurobehavioral toxicity of low-level in utero $\mathrm{Cd}$ exposure in rats. Neurobehavioral Toxicology and Teratology, 8(5), 463-468.

Di Vincenzo, A., Tana, C., El Hadi, H., Pagano, C., Vettor, R., \& Rossato, M. (2019). Antioxidant, anti-inflammatory, and metabolic properties of tocopherols and tocotrienols: Clinical implications for vitamin E supplementation in diabetic kidney disease. International Joumal of Molecular Sciences, 20(20), 5101.

El-Shahat, A. E., Gabr, A., Meki, A. R., \& Mehana, E. S. (2009). Altered testicular morphology and oxidative stress induced by cadmium in experimental rats and protective effect of simultaneous green tea extract. International Joumal of Morphology, 27(3), 757-764

Ercal, N., Gurer-Orhan, H., \& Aykin-Burns, N. (2001). Toxic metals and oxidative stress part I: Mechanisms involved in metal-induced oxidative damage. Current Topics in Medicinal Chemistry, 1(6), 529-539.

Fan, W., Wang, J., Wu, H., Lian, L., Du, S., \& Chen, L. (2015). Analysis of heavy metals monitoring results in food in Shaoxing in 2014. Wei Sheng Yan Jiu, 44(6), 922-927.

Fregoneze, J. B., Marinho, C. A., Soares, T., Castro, L., Sarmento, C., Cunha, M., Gonzalez, V., Oliveira, P., Nascimento, T., Luz, C. P., Santana Jr., P., De-Oliveira, I. R., \& e-Castro-e-Silva, E. (1997). Lead $\left(\mathrm{Pb}^{2+}\right)$ and cadmium $\left(\mathrm{Cd}^{2+}\right)$ inhibit the dipsogenic action of central beta-adrenergic stimulation by isoproterenol. Brazilian Joumal of Medical and Biological Research, 30(3), 419- 423.

Fryzova, R., Pohanka, M., Martinkova, P., Cihlarova, H., Brtnicky, M., Hladky, J., \& Kynicky, J. (2018). Oxidative stress and heavy metals in plants. Reviews of Environmental Contamination and Toxicology, 245, 129-156. 
Fu, Z., \& Xi, S. (2020). The effects of heavy metals on human metabolism. Toxicology Mechanisms and Methods, 30(3), 167-176.

Grymak, Y., Skoromna, O., Stadnytska, O., Sobolev, O., Gutyj, B., Shalovylo, S., Hachak, Y., Grabovska, O., Bushueva, I., Denys, G., Hudyma, V., Pakholkiv, N., Jarochovich, I., Nahimiak, T., Pavliv, O., Farionik, T., \& Bratyuk, V. (2020). Influence of "Thireomagnile" and "Thyrioton" preparations on the antioxidant status of pregnant cows. Ukrainian Journal of Ecology, 10(1), 122-126.

Gutyi, B., Ostapiuk, A., Kachmar, N., Stadnytska, O., Sobolev, O., Binkevych, V., Petryshak, R., Petryshak, O., Kulyaba, O., Naumyuk, A., Nedashkivsky, V., Nedashkivska, N., Magrelo, N., Golodyuk, I., Nazaruk, N., \& Binkevych, O. (2019). The effect of cadmium loading on protein synthesis function and functional state of laying hens' liver. Ukrainian Journal of Ecology, 9(3), 222-226.

Gutyj, B. V., Murs'ka, S. D., Gufrij, D. F., Hariv, I. I., Levkivs'ka, N. D., Nazaruk, N. V., Gajdjuk, M. B., Pryjma, O. B., Bilyk, O. J., \& Guta, Z. A. (2016). Influence of cadmium loading on the state of the antioxidant system in the organism of bulls. Visnyk of Dnipropetrovsk University, Biology, Ecology, 24(1), 96-102.

Gutyj, B. V., Ostapyuk, A. Y., Sobolev, O. I., Vishchur, V. J., Gubash, O. P., Kurtyak, B. M., Kovalskyi, Y. V., Darmohray, L. M., Hunchak, A. V., Tsisaryk, O. Y., Shcherbatyy, A. R., Farionik, T. V., Savchuk, L. B., Palyadichuk, O. R., \& Hrymak, K. (2019). Cadmium burden impact on morphological and biochemical blood indicators of poultry. Ukrainian Journal of Ecology, 9(1), 236-239.

Gutyj, B., Stybel, V., Darmohray, L., Lavryshyn, Y., Turko, I., Hachak, Y., Shcherbatyy, A., Bushueva, I., Parchenko, V., Kaplaushenko, A., \& Krushelnytska, O. (2017). Prooxidant-antioxidant balance in the organism of bulls (young cattle) after using cadmium load. Ukrainian Joumal of Ecology, 7(4), 589-596.

Ivankiv, M., Kachmar, N., Mazurak, O., \& Martyshuk, T. (2019). Hepatic protein synthesis and morphological parameters in blood of rats under oxidative stress and action of feed additive "Butaselmevit-plus". Ukrainian Journal of Ecology, 9(4), 628-633.

Järup, L. (2003). Hazards of heavy metal contamination. British Medical Bulletin, 68, 167-182.

Kalyn, B. M., Khromova, M. V., Vishchur, V. I., Butsiak, H. A., Kropyvka, S. I., \& Gutyj, B. V. (2020). Estimation of quality of surface water of Dniester river basin within Lviv and Khmelnytsk regions. Ukrainian Journal of Ecology, 10(6), 127-132.

Kogan, S., Sood, A., \& Garnick, M. S. (2017). Zinc and wound healing: A review of zinc physiology and clinical applications. Wounds, 29(4), 102-106.

Kozak, V. M., \& Brygadyrenko, V. V. (2018). Impact of cadmium and lead on Megaphyllum kievense (Diplopoda, Julidae) in a laboratory experiment. Biosystems Diversity, 26(2), 128-131.

Martyshuk, T. V., Gutyj, B. V., Zhelavskyi, M. M., Midyk, S. V., Fedorchenko, A. M., Todoriuk, V. B., Nahimiak, T. B., Kisera, Y. V., Sus, H. V., Chemerys, V. A., Levkivska, N. D., \& Iglitskej, I. I. (2020). Effect of Butaselmevit-Plus on the immune system of piglets during and after weaning. Ukrainian Journal of Ecology, 10(2), 347-352.

Muhamed, P. K., \& Vadstrup, S. (2014). Zinc is the most important trace element. Ugeskrift for Laeger, 176(5), V11120654.

Nazanuk, N., Gutyj, B. V., \& Hufriy, D. (2015). Influence of metifen and vitamix se on the activity of aminotransferases of bulls blood serum at cadmium nitrate loading. Scientific Messenger of LNU of Veterinary Medicine and Biotechnologies, Veterinary Sciences, 17(1), 121-126.

Piven, O. T., Khimych, M. S., Salata, V. Z., Gutyj, B. V., Naidich, O. V., Skrypka, H. A., Koreneva, Z. B., Dvylyuk, I. V., Gorobey, O. M., \& Rud, V. O. (2020). Contamination of heavy metals and radionuclides in the honey with different production origin. Ukrainian Journal of Ecology, 10(2), 405-409.

Pratush, A., Kumar, A., \& Hu, Z. (2018). Adverse effect of heavy metals (As, Pb, $\mathrm{Hg}$, and $\mathrm{Cr}$ ) on health and their bioremediation strategies: A review. International Microbiology, 21(3), 97-106.

Rahman, Z., \& Singh, V. P. (2019). The relative impact of toxic heavy metals (THMs) (arsenic (As), cadmium (Cd), chromium (Cr)(VI), mercury (Hg), and lead $(\mathrm{Pb})$ ) on the total environment: An overview. Environmental Monitoring and Assessment, 191(7), 419.
Rahman, Z., \& Singh, V. P. (2020). Bioremediation of toxic heavy metals (THMs) contaminated sites: Concepts, applications and challenges. Environmental Science and Pollution Research, 27(22), 27563-27581.

Rehman, K., Fatima, F., Waheed, I., \& Akash, M. S. H. (2018). Prevalence of exposure of heavy metals and their impact on health consequences. Joumal of Cellular Biochemistry, 119(1), 157-184.

Renu, K., Chakraborty, R., Myakala, H., Koti, R., Famurewa, A. C., Madhyastha, H., Vellingiri, B., George, A., \& Valsala Gopalakrishnan, A. (2021). Molecular mechanism of heavy metals (lead, chromium, arsenic, mercury, nickel and cadmium) - induced hepatotoxicity - A review. Chemosphere, 271, 129735.

Sall, M. L., Diaw, A. K. D., Gningue-Sall, D., Aaron, S. E., \& Aaron, J.-J. (2020). Toxic heavy metals: Impact on the environment and human health, and treatment with conducting organic polymers, a review. Environmental Science and Pollution Research, 27(24), 29927-29942.

Shulman, M. V., Pakhomov, O. Y., \& Brygadyrenko, V. V. (2017). Effect of lead and cadmium ions upon the pupariation and morphological changes in Calliphora vicina (Diptera, Calliphoridae). Folia Oecologica, 44(1), 28-37.

Slivinska, L. G., Shcherbatyy, A. R., Lukashchuk, B. O., Zinko, H. O., Gutyj, B. V., Lychuk, M. G., Chemushkin, B. O., Leno, M. I., Prystupa, O. I., Leskiv, K. Y., Slepokura, O. I., Sobolev, O. I., Shkromada, O. I., Kysterna, O. S., \& Musiienko, O. V. (2019). Correction of indicators of erythrocytopoesis and microelement blood levels in cows under conditions of technogenic pollution. Ukrainian Joumal of Ecology, 9(2), 127-135.

Slobodian, S. O., Gutyj, B. V., \& Leskiv, K. Y. (2019). The level of lipid peroxidation products in the rats blood under prolonged cadmium and lead loading. Ukrainian Joumal of Veterinary and Agricultural Sciences, 2(3), 15-18.

Slobodian, S., Gutyj, B., Gufriy, D., Hnativ, P., \& Murska, S. (2020). The effect of sodium selenite and feed additive "Metisevit plus" on the protein-synthesizing function and functional state of the liver of rats under prolonged cadmium and lead loading. Scientific Messenger of LNU of Veterinary Medicine and Biotechnologies, Veterinary Sciences, 100, 54-59.

Sobolev, O., Gutyj, B., Petryshak, R., Pivtorak, J., Kovalskyi, Y., Naumyuk, A., Petryshak, O., Semchuk, I., Mateusz, V., Shcherbatyy, A., \& Semeniv, B. (2018). Biological role of selenium in the organism of animals and humans. Ukrainian Journal of Ecology, 8(1), 654-665.

Stoyanovskyy, V., Usenko, S., Shostya, A., Kuzmenko, L., Slynko, V., \& Tenditnyk, V. (2020). Hormonal regulation of prooxidant-antioxidant homeostasis in gilts. Ukrainian Journal of Veterinary and Agricultural Sciences, 3(3), $39-43$.

Tombarkiewicz, B., Trzeciak, K., Bojarski, B., \& Lis, M. W. (2020). The effect of methionine and folic acid administered in ovo on the hematological parameters of chickens (Gallus gallus domesticus). Poultry Science, 99(9), 4578-4585.

Vasylyev, D., Priimenko, B., Aleksandrova, K., Mykhalchenko, Y., Gutyj, B., Mazur, I., Magrelo, N., Sus, H., Dashkovskyy, O., Vus, U., \& Kamratska, O. (2021). Investigation of the acute toxicity of new xanthine xenobiotics with noticeable antioxidant activity. Ukrainian Journal of Ecology, 11(1), 315-318.

Vishchur, V. Y., Gutyj, B. V., Nischemenko, N. P., Kushnir, I. M., Salata, V. Z., Tarasenko, L. O., Khimych, M. S., Kushnir, V. I., Kalyn, B. M., Magrelo, N. V., Boiko, P. K., Kolotnytskyy, V. A., Velesyk, T., Pundyak, T. O., Gubash, O. P. (2019). Effect of industry on the content of fatty acids in the tissues of the honey-bee head. Ukrainian Journal of Ecology, 9(3), 174-179.

Vlislo, V. V. (2012). Laboratomi metody doslidzhen u biolohii, tvarynnytstvi ta veterynarniy medytsyni [Laboratory methods of research in biology, animal husbandry and veterinary medicine]. Spolom, Lviv (in Ukrainian).

Yang, C. S., Luo, P., Zeng, Z., Wang, H., Malafa, M., \& Suh, N. (2020). Vitamin E and cancer prevention: Studies with different forms of tocopherols and tocotrienols. Molecular Carcinogenesis, 59(4), 365-389.

Yaroshevych, N. B., Gutyj, B. V., Hrymak, O. Y., Kushnir, L. P., Kalaitan, T. V., Kondrat, I. Y., \& Shevchuk, O. O. (2021). The state of environmental taxation in Ukraine and the main directions of reform. Ukrainian Joumal of Ecology, 11(1), 350-359.

Zazharska, N., Boyko, O., \& Brygadyrenko, V. (2018). Influence of diet on the productivity and characteristics of goat milk. Indian Journal of Animal Research, 52(5), 711-717. 